\title{
Improving Science Learning Outcomes Through CTL Learning Model Assisted by Audiovisual Media for Fourth Grade Students at SDN Pagerkukuh
}

\author{
Desy Ikariani \\ SD Negeri Pagerkukuh \\ desyika10@gmail.com
}

\section{Article History}

received 3/12/2020

revised $17 / 12 / 2020$

accepted $31 / 12 / 2020$

\begin{abstract}
The background of this research problem is obtained from the results of reflections that show problems in science learning in class IV SDN Pagerkukuh including students learning to the extent of receiving knowledge from the teacher, less optimal group work is formed, low learning motivation. This has an impact on learning outcomes where 29 out of 41 students have not reached the KKM. The purpose of this study was to improve student learning outcomes in science learning in class IV SDN Pagerkukuh. The research conducted was Classroom Action Research which was carried out in two cycles. The results showed that the learning outcomes with classical completeness in the first cycle were $71 \%$, increased in the second cycle to $83 \%$. The conclusion of this research is that through the CTL learning model assisted by audiovisual media can improve science learning outcomes.
\end{abstract}

Keywords: quality of learning, CTL, audiovisual

\begin{abstract}
Abstrak
Latar belakang masalah penelitian ini diperoleh dari hasil refleksi yang menunjukkan permasalahan dalam pembelajaran IPA di kelas IV SDN Pagerkukuh diantaranya siswa belajar sebatas menerima pengetahuan dari guru, kurang dibentuk kerja kelompok secara optimal, motivasi belajar rendah. Hal tersebut berdampak terhadap hasil belajar di mana 29 dari 41 siswa belum mencapai KKM. Tujuan penelitian ini adalah untuk meningkatkan hasil belajar siswa dalam pembelajaran IPA di kelas IV SDN Pagerkukuh. Penelitian yang dilakukan adalah Penelitian Tindakan Kelas yang dilaksanakan dalam dua siklus. Hasil penelitian menunjukkan bahwa hasil belajar dengan ketuntasan klasikal pada siklus I $71 \%$, meningkat pada siklus II menjadi $83 \%$. Simpulan dari penelitian ini adalah melalui model pembelajaran CTL berbantuan media audiovisual dapat meningkatkan hasil belajar IPA. Abstrak dalam bahasa Indonesia mengikuti kaidah dalam Pedoman Umum Ejaan Bahasa Indonesia (PUEBI).
\end{abstract}

Kata kunci: kualitas pembelajaran IPA, CTL, audiovisual

Social, Humanities, and Education Studies (SHEs): Conference Series https://jurnal.uns.ac.id/shes

p-ISSN 2620-9284

e-ISSN 2620-9292 


\section{PENDAHULUAN}

Tuntutan manusia yang berkualitas dapat terpenuhi melalui suatu rangkaian proses yang panjang, khususnya dengan memberikan pendidikan yang dimulai pada anak usia Sekolah Dasar. Pendidikan yang diberikan pada anak nantinya dapat menentukan kualitas Sumber Daya Manusia (SDM). Kualitas SDM yang baik dapat diandalkan untuk mengelola Sumber Daya Alam yang ada di lingkungan sekitar. Salah satu mata pelajaran yang berperan dalam meningkatkan kualitas SDM yaitu IPA (IImu Pengetahuan Alam).

IPA adalah mata pelajaran yang berkaitan langsung dengan diri sendiri, alam sekitar, bertujuan memberikan bekal pengalaman secara langsung pada siswa agar terbentuk sikap kritis, ilmiah, kreatif, serta tanggap terhadap permasalahan yang terjadi dalam kehidupan sehari-hari. Oleh karena itu, tiap siswa diharapkan dapat memperoleh hasil belajar yang baik sebagai cerminan keberhasilan pembelajaran IPA.

Pembelajaran IPA saat ini menekankan proses membelajarkan bagaimana belajar, serta mengutamakan strategi mendorong dan melancarkan proses belajar siswa. Hal ini sejalan dengan teori belajar konstruksivisme yang menyatakan bahwa siswa secara aktif mencari sendiri informasi, mengasimilasi, dan mengadaptasi sendiri informasi, serta mengkonstruksinya menjadi pengetahuan yang baru berdasarkan pengetahuan yang telah dimiliki masing-masing (Lapono, 2011:14).

Pada dasarnya tujuan yang terkandung dalam KTSP sudah baik karena mengandung ide-ide yang dapat mengantisipasi perkembangan IPTEK secara global. Namun kenyataan yang terjadi di sekolah-sekolah masih banyak ditemukan permasalahan pelaksanaan pembelajaran yang belum sesuai tuntutan KTSP, sehingga masih perlu peningkatan kualitas pembelajaran IPA.

Permasalahan pembelajaran IPA dialami oleh guru kelas IV SDN Pagerkukuh. Berdasarkan hasil analisis terhadap rata-rata nilai ulangan harian di kelas IV SDN Pagerkukuh pada mata pelajaran IPA masih banyak siswa yang belum mencapai Kriteria Ketuntasan Minimal (KKM) yang ditetapkan yaitu 65. Rata-rata nilai ulangan harian di kelas IV SDN Pagerkukuh pada mata pelajaran IPA diperoleh nilai tertinggi 81,5 dan nilai terendah 36,5 . Terlihat dari data 41 siswa hanya 12 siswa $(29,26 \%)$ yang mendapatkan nilai rata-rata ulangan harian di atas Kriteria Ketuntasan Minimal (KKM) yaitu 65 , sedangkan sisanya 29 siswa $(70,74 \%)$ nilai rata-rata ulangan harian mengalami ketidaktuntasan (dibawah KKM 65). Masalah pada pembelajaran di kelas dapat dirumuskan sebagai berikut: Bagaimanakah cara meningkatkan hasil belajar IPA melalui penerapan model pembelajaran CTL berbantuan media audiovisual pada kelas IV SDN Pagerkukuh?

Permasalahan yang terjadi perlu dipecahkan melalui penerapan pembelajaran inovatif yang diharapkan dapat meningkatkan hasil belajar IPA. Pada pembelajaran inovatif, peran guru tidak hanya sebagai transformator (penerjemah), evaluator (penilai), dan motivator (membangkitkan motivasi) melainkan sebagai fasilitator (memfasilitasi media, dan sumber belajar). Filosofi dari pembelajaran inovatif adalah siswa belajar secara konstruktivis yaitu menemukan sendiri, mengkonstruksi pengetahuan melalui interaksi dengan lingkungan sebagai sumber belajar. Berdasarkan hasil penelitian berpijak pada teori kontruktivisme, maka peneliti menetapkan alternatif tindakan dengan menerapkan model pembelajaran CTL (Contextual Teaching And Learning).

Model pembelajaran CTL adalah model pembelajaran yang dimulai dengan sajian atau tanya jawab lisan (ramah, terbuka, negosiasi) yang terkait dengan dunia nyata kehidupan siswa (daily life modeling), sehingga akan terasa manfaat dari materi yang akan disajikan, motivasi belajar muncul, dunia pikiran siswa menjadi kongkret, dan suasana menjadi kondusif-nyaman dan menyenangkan. (Suyatno, 2010:56-57).

Ciri khas CTL ditandai dengan tujuh komponen utama, yaitu: konstruktivisme, inquiri, bertanya, masyarakat belajar, pemodelan, refleksi, dan penilaian autentik. Dari 
tujuh komponen tersebut siswa dapat saling bekerja sama, belajar untuk mencoba berfikir kritis dan mengembangkan kreatifitas. Selain itu CTL juga dapat memberikan kesempatan lebih banyak pada siswa untuk melakukan, mencoba dan mengalami sendiri serta belajar dari berbagai sumber belajar (Rusman, 2012:190).

\section{METODE}

Penelitian ini adalah Peneliian Tindakan Kelas dengan menerapkan model pembelajaran CTL (Contextual Teaching And Learning). Menurut (Aqib dkk, 2010:8) penelitian tindakan kelas ini terdiri dari empat tahapan yaitu merencanakan perbaikan, melaksanakan tindakan, mengamati, dan melakukan refleksi. Analisis data menggunakan analisis deskriptif kualitatif dan analisis statistik deskriptif kuantitatif. Subjek penelitian adalah guru dan siswa kelas IV SDN Pagerkukuh Tahun Pelajaran 2015/2016. Pelaksanaan tindakan pada siklus I dilaksanakan dalam dua kali pertemuan. Pertemuan pertama dilaksanakan pada tanggal 17 Maret 2016 dan pertemuan kedua dilaksanakan pada tanggal 24 Maret 2016. Pelaksanaan tindakan pada siklus II dilaksanakan dalam satu kali pertemuan. Pertemuan dilaksanakan pada tanggal 4 April 2016. Teknik pengumpulan data menggunakan tes dan nontes.

\section{HASIL DAN PEMBAHASAN}

Pada siklus I pembelajaran dilaksanakan selama dua pertemuan, setiap pertemuan diadakan pre test dan post test untuk menetahui perkembangan siswa selama belajar. Berdasarkan tabel dan diagram hasil observasi peningkatan hasil belajar dalam pembelajaran IPA di kelas IV SDN Pagerkukuh melalui model pembelajaran CTL berbantuan media audiovisual di bawah ini menunjukkan bahwa hasil belajar siswa meningkat antara siklus I dan II dengan penjelasan sebagai berikut:

Tabel 1. Data Hasil Belajar Siklus I dan Siklus II

\begin{tabular}{lcc}
\hline Data hasil belajar & Siklus I & Siklus II \\
\hline Nilai Rata-rata & 70 & 74 \\
Nilai Terendah & 40 & 40 \\
Nilai Tertinggi & 100 & 100 \\
Siswa Tuntas Belajar & 29 & 34 \\
Siswa Tidak Tuntas Belajar & 12 & 7 \\
Persentase Ketuntasan & $71 \%$ & $83 \%$ \\
\hline
\end{tabular}

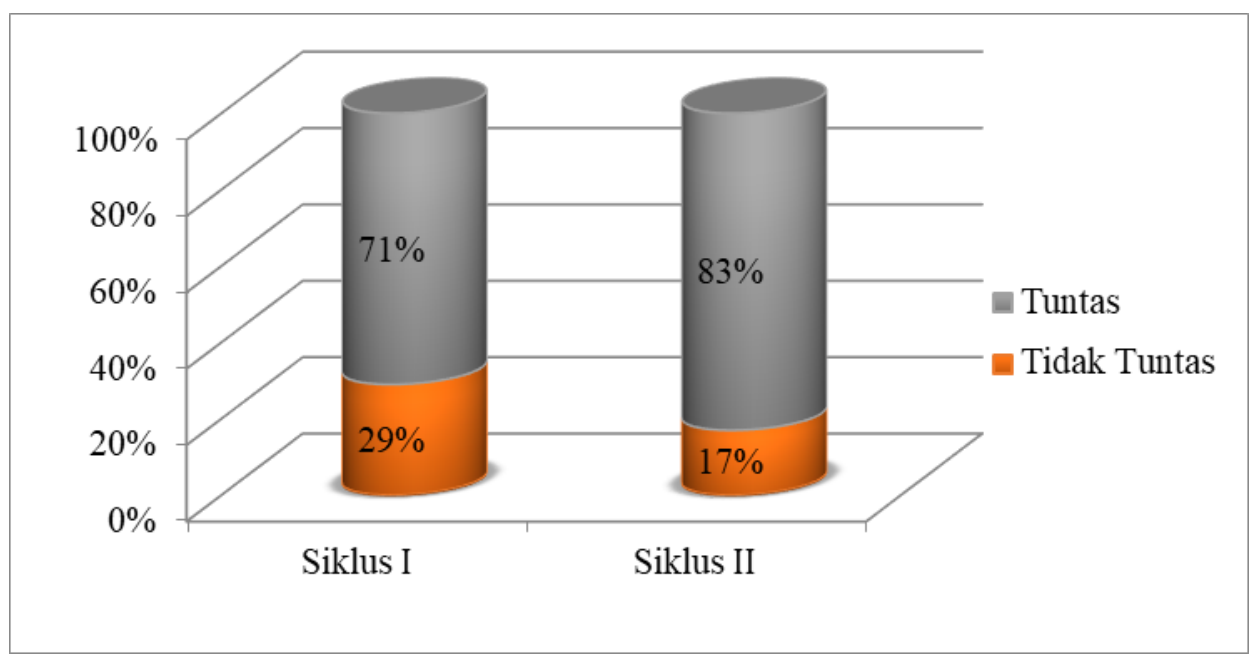

Gambar 1. Persentase Ketuntasan Hasil Belajar Siklus I dan Siklus II 
Berdasarkan tabel dan diagram, terjadi peningkatan hasil belajar dari siklus I sampai siklus II. Pada siklus I memperoleh nilai terendah 40, rata-rata dan nilai tertinggi 100, siswa yang belum tuntas sebanyak 12 dan yang sudah tuntas sebanyak 29 , pada siklus I presentase ketuntasan belajar klasikal adalah sebesar $71 \%$ namun harus dilaksanakan siklus II karena belum memenuhi indikator keberhasilan dimana ketuntasan belajar baik sekurang-kurangnya $80 \%$.

Pada siklus II terjadi peningkatan nilai hasil belajar siswa yaitu nilai rata-rata sebesar 76 dengan nilai terendah 45 dan tertinggi 100, pada siklus II siswa yang belum tuntas sebanyak 7 siswa dan siswa yang tuntas dalam belajar 34 siswa, di siklus II ini presentase ketuntasan belajar klasikal mencapai $83 \%$.

Menurut data di atas kenaikan hasil belajar serta ketuntasan klasikal dari siklus I sampai siklus II, dari $71 \%$ menjadi $83 \%$. Terjadinya kenaikan hasil belajar dikarenakan dalam tahap pembelajaran guru melakukan kegiatan secara terencana dan sistematis.

Berdasar indikator keberhasilan yang ditetapkan, kriteria ideal ketuntasan adalah sekurang-kurangnya $80 \%$. Berdasarkan nilai belajar siswa pada siklus I menunjukkan bahwa presentase ketuntasan belajar klasikla belum mencapai $80 \%$. Hal ini ditunjukkan dari ketuntasan yang dicapai hanya $71 \%$ dengan jumlah siswa yang tuntas sebanyak 29 dari 41 siswa. Setelah dilaksanakan siklus II menunjukkan bahwa presentase ketuntasan siswa mencapai $83 \%$ dengan jumlah siswa yang tuntas belajar sebanyak 34 dari 41 siswa.

Dengan demikian berdasarkan nilai ketuntasan klasikal maka penelitian ini berhenti sampai di siklus II. Dalam penelitian yang telah dilakukan terlihat adanya peningkatan hasil belajar siswa. Hal ini dapat membuktikan bahwa model pembelajaran CTL berbantuan media audiovisual cocok untuk diterapkan dalam pembelajaran IPA di kelas IV SDN Pagerkukuh.

Secara teoritis implikasi dari penelitian ini yaitu keterkaitan antara hasil penelitian dengan teori-teori yang digunakan oleh peneliti. Penelitian ini membuka wawasan bagi guru terhadap model pembelajaran CTL berbantuan media audiovisual mampu meningkatkan keterampilan guru dalam mengajar terutama dalam hal memotivasi dan memfasilitasi siswa dalam melakukan penyelidikan. Hal ini sesuai dengan pendapat Sutikno (2010) bahwa kedudukan guru mempunyai arti penting dalam pendidikan mengingat tugas serta tanggung jawab mencerdaskan siswanya.

Dalam proses pembelajaran IPA melalui model pembelajaran CTL berbantuan media audiovisual di kelas IV SDN Pagrkukuh memberikan peluang kepada siswa untuk ikut berpartisipasi dalam proses pembelajaran. Melalui kegiatan konstruktivis, siswa membangun pengetahuan baru berdasarkan pengetahuan lama yang dimiliki melalui interaksi sumber belajarnya. Siswa dilatih terampil untuk mengemukakan pendapat dengan bertanya maupun menjawab pertanyaan baik dari guru maupun siswa lain. Kegiatan inkuiri memberikan kesempatan siswa mencari, menemukan sendiri pengetahuan berdasarkan pengamatan atau percobaan yang dilakukan sehingga pembelajaran lebih bermakna karena pengalaman belajar di sekolah dihubungkan dengan situasi nyata. Belajar dengan berkelompok akan menumbuhkan rasa saling menghargai pendapat, bertanggung jawab, saling membantu, kerjasama di antara siswa sehingga pembelajaran akan lebih menyenangkan. Selain itu, melalui pemodelan dapat menumbuhkan rasa percaya diri, berani, bertanggung jawab dalam diri siswa.

Hasil penelitian ini juga sesuai dengan penelitian sebelumnya yang dilakukan oleh Panji Kusumah (2011) yang membuktikan bahwa model pembelajaran CTL (Contextual Teaching And Learning) dapat meningkatkan pembelajaran IPA.

\section{SIMPULAN}

Hasil belajar siswa dalam pembelajaran IPA melalui penerapan model pembelajaran CTL berbantuan media audiovisual mengalami peningkatan. 
Berdasarkan hasil siklus I diperoleh nilai rata-rata 74,84 , siklus II meningkat menjadi 76. Persentase ketuntasan belajar siklus I sebesar $71 \%$ atau 29 dari 41 siswa, meningkat menjadi $83 \%$ atau sebanyak 34 siswa dari 41 siswa pada siklus II sehingga penelitian ini dinyatakan berhasil. Model pembelajaran CTL berbantuan media audiovisual hendaknya diterapkan dalam pembelajaran IPA karena mampu meningkatkan keterampilan guru dalam mengajar terutama dapat membantu guru mengaitkan materi yang diajarkan dengan situasi nyata dan mendorong siswa membuat hubungan antara pengetahuan yang dimiliki dengan kehidupan sehari-hari. dapat menumbuhkan keterampilan interpersonal meliputi: berani bertanya, kerjasama, partisipasi aktif, menghargai pendapat teman, berbagi tugas mengambil giliran, tidak meninggalkan tempat duduk sebelum tugas selesai, bertanggung jawab, serta memberikan pengalaman belajar lebih bermakna bagi siswa karena berinteraksi langsung dengan sumber atau bahan ajar yang dipelajari.

\section{DAFTAR PUSTAKA}

Arikunto, Suharsimi. 2010. Prosedur Penelitian. Yogyakarta: Pustaka Belajar Aqib, Zainal, dkk. 2009. Penelitian Tindakan Kelas. Bandung: Yrama Widya.

Daryanto. 2011. Penelitian Tindakan Kelas dan Penelitian Tindakan Sekolah. Yogyakarta: Gava Media.

Ervina, Yulia. 2013. Penerapan Model pembelajaran Contextual Teaching And Learning (CTL) Untuk Meningkatkan Hasil Belajar IPA Tentang Perubahan Kenampakan Bumi.

Lapono, Nabisi. 2011. Belajar dan Pembelajaran. Jakarta: Direktorat Jenderal Pendidikan Tinggi Departemen Pendidikan Nasional.

Kesumah, Panji. 2011. Meningkatkan pembelajaran IPA melalui pendekatan CTL pada siswa kelas V SDN Panggungrejo kota Pasuruan. http://library.um.ac.id/ptk/ index.php?mod=detail\&id=48728/. [accesed 23 Januari 2016].

Kurikulum 2013. 2013. Kompetensi Dasar. Jakarta: Kementrian Pendidikan dan Kebudayaan.

Rusman. 2012. Model-model Pembelajaran Mengembangkan Profesionalisme Guru. Jakarta: PT Rajawali Pers.

Sani, Ridwan Abdullah. 2013. Inovasi Pembelajaran. Jakarta: Bumi Aksara.

Suprijono, Agus. 2013. Cooperatif Learning “Teori dan Aplikasi Pakem”. Yogyakarta: Pustaka Belajar.

Suyatno. 2010. Pembelajaran Inovatif. Surabaya: Masmedia Buana Pustaka. 